\title{
Study, preparation and characterization of thiosemicarbazone ligands and their compounds
}

\author{
Paula Munín*a, Fátima Lucio-Martínez ${ }^{\mathrm{a}}$, Adolfo Fernandez-Figueiras ${ }^{\mathrm{a}}$, Francisco \\ Reigosa $^{a}$, José M. Vila ${ }^{a}$, M. Teresa Pereira ${ }^{a}$, Juan M. Ortigueira ${ }^{a}$ \\ ${ }^{a}$ Department of Inorganic Chemistry, University of Santiago de Compostela, Spain \\ E-mail: muninchy@hotmail.com
}

\begin{abstract}
Thiosemicarbazones are formed by the condensation of an aldehyde or ketone with a thiosemicarbazide. They have high coordinative capacity given that they have several potential donor atoms through which they can bind to transition metals. This coordinative capacity can be increased if the R1 and R2 substituents include additional donor atoms. In addition, thiosemicarbazones as well as their semicarbazones analogues have considerable biological and pharmacological interest because of their antibacterial, antiviral and antitumor activity [1-2].
\end{abstract}

This communication includes the preparation and characterization of a series of thiosemicarcarbazones and their applications in the synthesis of palladium organometallic compounds [3-4].

\section{Keywords}

Thiosemicarbazones, metallacycle, palladium.

\section{Introduction}

Thiosemicarbazone compounds display very interesting properties in the field of biomedicine as cytotoxic and antitumor species [5-6]. In this communication a family of thiosemicarbazone cyclometallated palladium compounds is presented, which may possess cytotoxic properties [7-9]; it is also well known that palladium compounds show catalytic properties for cross-coupling reactions [10-11]. We include herein the discussion related to the synthesis of palladium derivatives for the purpose of pursuing new properties and applications. 


\section{Results and discussion}

Thiosemicarbazone ligands have high coordinative ability since they possess several potentially donor atoms through which they can coordinate metals. Scheme 1 shows the synthesis of the ligands presented in this communication.

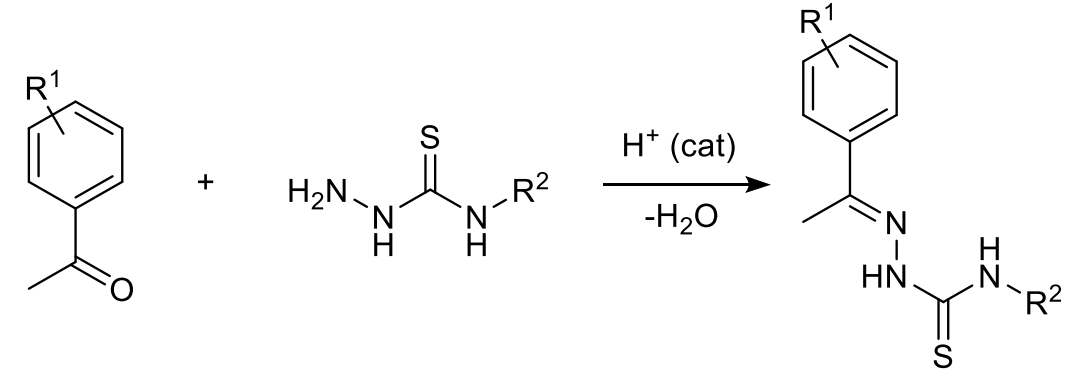

$\mathrm{R}^{1}=4-\mathrm{Br}, 3-\mathrm{OMe} ; \mathrm{R}^{2}=\mathrm{H}, \mathrm{Me}, \mathrm{Et}, \mathrm{Ph}$

Scheme 1.

In the literature cyclometallated palladium and platinum compounds with thiosemicarbazone ligands have been described [12]; they show a tetranuclear structure (Figure 1) containing two types of metal-S bonds: metal- $S_{\text {chelate }}$ and metal- $S_{\text {bridging }}$. Palladium is bonded to carbon and coordinated to a nitrogen atom and to two different sulfur atoms.

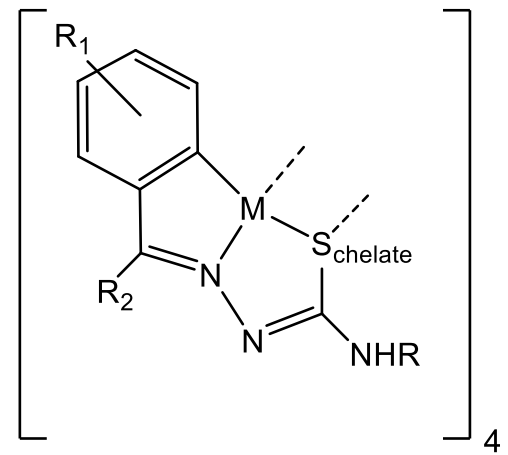

Figure1.

In the present case, palladium is bonded to phenyl ring, and it is coordinated to the imine nitrogen and $S_{\text {chelate }}$ and $S_{\text {bridging }}$ sulfur atoms, one of which is part of an adjacent metallated moiety. The metallation step is shown in Scheme 2,
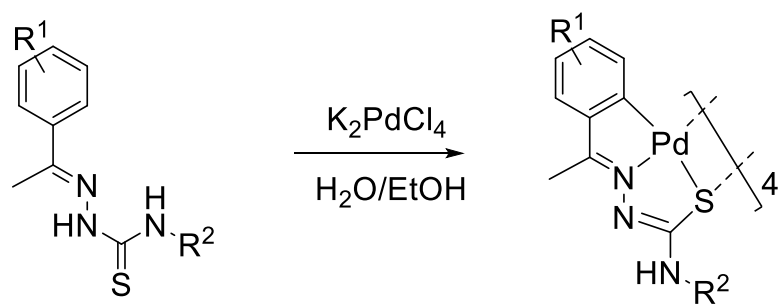

$\mathrm{R}^{1}=4-\mathrm{Br}, 3-\mathrm{OMe} ; \mathrm{R}^{2}=\mathrm{H}, \mathrm{Me}, \mathrm{Et}, \mathrm{Ph}$

Scheme 2. 
The ${ }^{1} \mathrm{H}$ NMR data confirm formation of the ligand and of the compounds. In the spectra of the latter the $\mathrm{C}(2)$ proton resonance and the hydrazinic proton resonance $\mathrm{NNH}$, are absent.

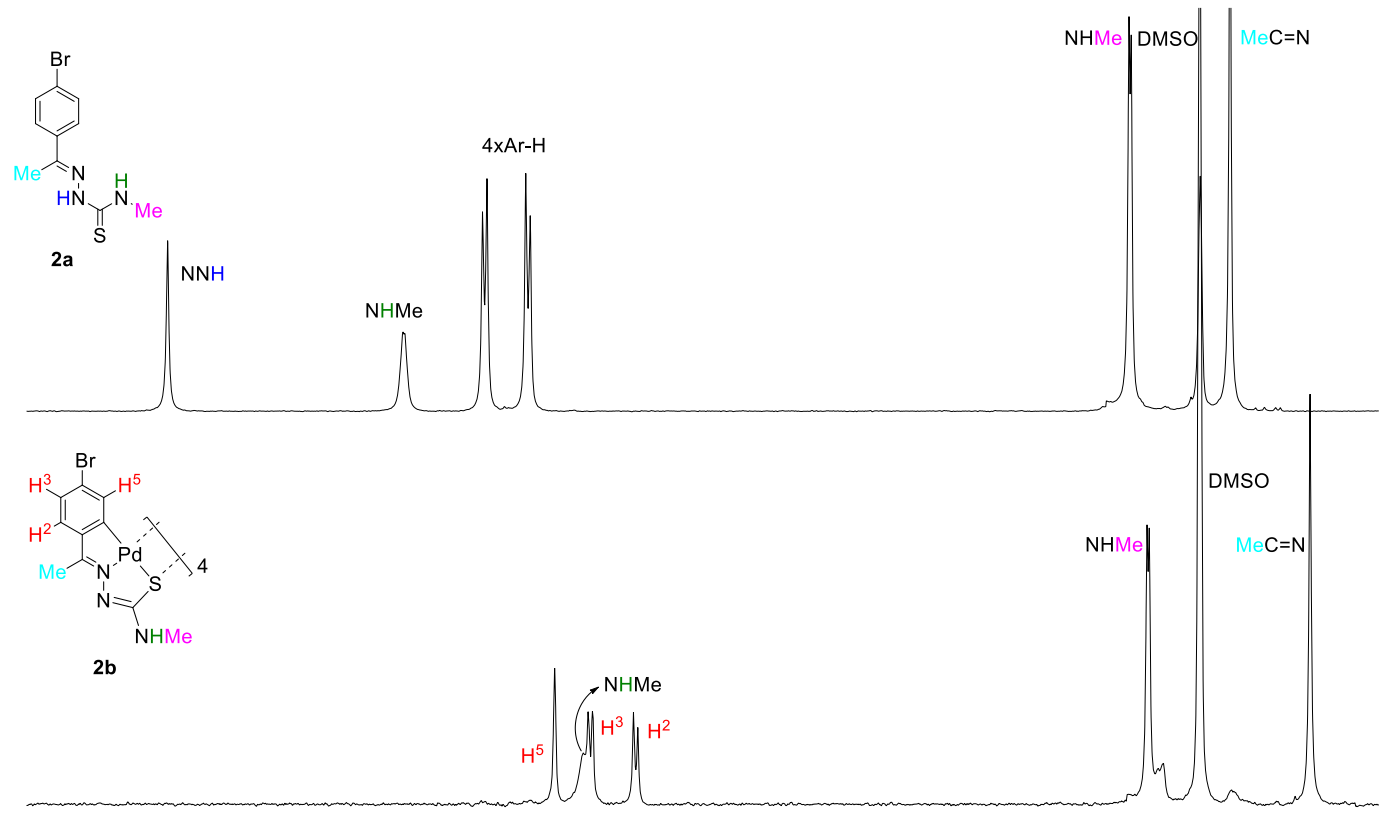

$\begin{array}{llllllllllllllllllll}11.0 & 10.5 & 10.0 & 9.5 & 9.0 & 8.5 & 8.0 & 7.5 & 7.0 & 6.5 & 6.0 & 5.5 & 5.0 & 4.5 & 4.0 & 3.5 & 3.0 & 2.5 & 2.0 & 1.5\end{array}$

Figure 2. ${ }^{1} \mathrm{H}$ NMR spectrum for ligand $2 \mathrm{a}$ (top) and compound $2 \mathrm{~b}$ (bottom)

The IR spectra show that the hydrazinic $v(\mathrm{~N}-\mathrm{H})$ and the $v(\mathrm{C}=\mathrm{S})$ stretchs are absent in the complexes, confirming deprotonation of the $\mathrm{NH}$ group and loss of the $\mathrm{C}=\mathrm{S}$ double bond character.

\begin{tabular}{cccc}
\hline Ligand & $\mathbf{v}(\mathbf{N}-\mathbf{H})$ & Compound & $\mathbf{v}(\mathbf{N}-\mathbf{H})$ \\
\hline $\mathbf{1 a}$ & $3240 / 3329 / 3415$ & $\mathbf{1 b}$ & $3427 / 3498$ \\
$\mathbf{2 a}$ & $3219 / 3387$ & $\mathbf{2 b}$ & 3425 \\
$\mathbf{3 a}$ & $3241 / 3335$ & $\mathbf{3 b}$ & 3427 \\
$\mathbf{4 a}$ & $3158 / 3241 / 3366$ & $\mathbf{4 b}$ & $3342 / 3460$ \\
$\mathbf{5 a}$ & $3237 / 3358$ & $\mathbf{5 b}$ & 3406 \\
$\mathbf{6 a}$ & $3226 / 3351$ & $\mathbf{6 b}$ & 3428 \\
$\mathbf{7 a}$ & $3220 / 3295$ & $\mathbf{7 b}$ & 3406 \\
\hline
\end{tabular}

Table 1. 
Suitable crystals for X-ray diffraction were possible. The structure of the ligand is essentially planar; the tetranuclear complexes show two mutually perpendicular sets of parallel metallated moieties. Palladium and sulfur atoms are arranged in a boat-boat type structure.

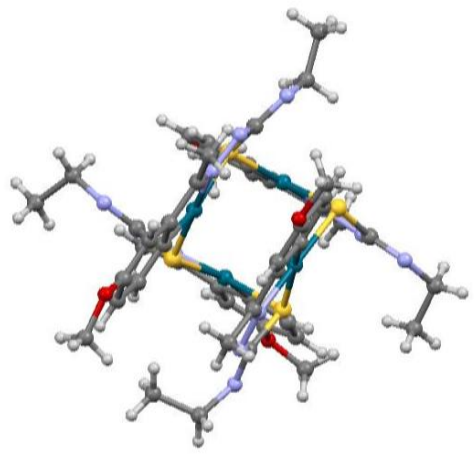

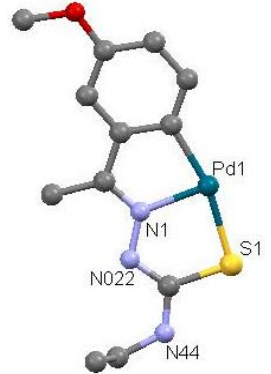

Figure 3.
Empirical formula

Formula weight

Temperature

Wavelength

Crystal system

Space group

Unit cell dimensions

Volumen

Z

Density (calculated)

Absorption coefficient

$\mathrm{F}(000)$

Crystal size
$\mathrm{C}_{50} \mathrm{H}_{63} \mathrm{Cl}_{6} \mathrm{~N}_{12} \mathrm{O}_{4} \mathrm{Pd}_{4} \mathrm{~S}_{4}$

1662,66

293(2) K

$0,71073 \AA$

Monoclinic

Ia

$a=14,068(5) \AA, \alpha=90,000(5)^{\circ}$

$b=32,485(5) \AA, \beta=106,932(5)^{\circ}$

$c=14,446(5) \AA, \gamma=90,000(5)^{\circ}$

$$
\text { 6316(3) } \AA^{3}
$$

2

$0,874 \mathrm{mg} / \mathrm{m}^{3}$

$0,780 \mathrm{~mm}^{-1}$

1658

$0,30 \times 0,16 \times 0,10 \mathrm{~mm}^{3}$

Theta $(\theta)$ range for data collection $1,60-26,37^{\circ}$

Index ranges $h, k, l$

$-17 \leq h \leq 17,-40 \leq k \leq 40,-18 \leq l \leq 18$

Reflections collected

47031

Independent reflections

$12848[\mathrm{R}($ int $)=0,0334]$

12848 / 2 / 735

1,157

Goodness-of-fit-on $\mathrm{F}^{2}$

$R_{1}=0,0336, w R_{2}=0,0817$

$\mathrm{R}$ indices (all data )

$R_{1}=0,0369, w R_{2}=0,0866$

Largest diff. peak and hole
1,378 y $-0,670$ e/ $/{ }^{3}$ 


\section{Experimental}

\section{Ligands}

Radley's tube the thiosemicarbazide was dissolved in distilled water $\left(20 \mathrm{~cm}^{3}\right)$ under stirring at room temperature. Then, hydrochloric acid $\left(0,4 \mathrm{~cm}^{3}\right)$ was added. After complet solution the ketone was added. A solid appeared after stirring for $8 \mathrm{~h}$, which was filtered off, washed with water and dried under vacuum.

\section{Complexes:}

In a Radley's tube a solution of potassium tetrachloropalladate solution is prepared in water under stirring. Then ethanol $\left(10 \mathrm{~cm}^{3}\right)$ and the appropriate amount of thiosemicarbazone were added. The mixture was stirred for $24 \mathrm{~h}$ at $\mathrm{r}$. t. The resulting suspension was centrifuged and the solid was taken to dryness under vacuum.

\section{Acknowledgements}

We wish to thank the financial support received from the Xunta de Galicia (Galicia, Spain) under the Grupos de Referencia Competitiva Programme Projects GRC2015/009.

F. Lucio-Martínez and F. Reigosa thank the Spanish Ministry of Education (grant FPU13/05014 and FPU15/07145).

\section{References}

[1] S. Cruz; S. Bernés; P. Sharma; R. Vazquez; G. Hernandez; R. Potillo; R. Gutierrez, Appl. Organomet. Chem., 2010, 24, 8.

[2] A. Garoufis; S. K. Hadjikakou; N. Hadjiliadis, Coord. Chem. Rev., 2009, 253, 1384.

[3] P. Kalaivani; R. Prabhakaran; F. Dallemer; P. Poornima; E. Vaishnavi; E. Ramachandran; V. V. Padma; R. Renganathan; K. Natarajan, Metallomics, 2012, 4, 101.

[4] E. Budzisz; R. Bobka; A. Hauss; J. N. Roedel; S. Wirth; I. P. Lorenz; B. Rozalska; M. Wieckowska-Szakiel; U. Krajewska; M. Rozalski, Dalton Trans., 2012, 41, 5925.

[5] S. Cruz; S. Bernès; P. Sharma; R. Vazquez; G. Hernández; R. Portillo; R. Gutiérrez, Appl. Organomet. Chem., 2010, 24, 8.

[6] A. Garoufis; S. K. Hadjikakou; N. Hadjiliadis, Coord. Chem. Rev., 2009, 253, 1384.

[7] A. A. Ibrahim; H. Khaledi; P. Hassandarvish; H. Mohd Ali; H. Karimian, Dalton Trans., 2014, 43, 3850.

[8] A. I. Matesanz; C. Hernandez; A. Rodriguez; P. Souza, Dalton Trans., 2011, 40, 5738.

[9] P. Kalaivani; R. Prabhakaran; F. Dallemer; P. Poornima; E. Vaishnavi; E. Ramachandran; V. V. Padma; R. Renganathan; K. Natarajan, Metallomics, 2012, 4, 101.

[10] Kostas, I. D.; Andreadaki, F. J.; Kovala-Demertzi, D.; Christos, P.; Demertzis, M. A. Tetrahedron Letters 2005, 46, 1967.

[11] Kovala-Demertzi, D.; Kourkoumelis, N.; Derlat, K.; Michalak, J.; Andreadaki, F. J.; Kostas, I. D. Inorg. Chim. Acta 2008, 361, 1562.

[12] J. M. Antelo, Ph.D. Dissertation, Universidad de Santiago de Compostela, 2009. 